\title{
COMMENTS
}

\section{PRESUMPTIONS-THE UNIFORM RULES IN THE FEDERAL COURTS}

$\mathrm{L}$ EGAL commentators have long recognized that basic reform is needed in several areas of evidence law and that greater uniformity in the rules of evidence among jurisdictions would promote a sounder administration of justice. Professor Thayer laid the keystone to evidence reform when he urged that "rules of evidence should be simplified; and should take on the general character of principles, to guide the sound judgment of the judge." II In 1942 the American Law Institute, concerning itself with the admissibility rather than the weight to be ascribed to evidence, adopted the Model Code of Evidence, in an attempt to reform and codify evidence law. ${ }^{2} \mathrm{Al}-$ though many commentators applauded this massive effort, the Model Code received little acceptance as a practical vehicle for evidence reform. Criticism was leveled primarily at the academic language employed, the great discretion given the trial judge, and the liberality of certain portions of the Model Code. ${ }^{3}$

Not until adoption of the Uniform Rules of Evidence in 1953 by the National Conference of Commissioners on Uniform State Laws was there a substantial movement for evidence reform outside academic circles. ${ }^{4}$ The drafters of the Uniform Rules used the Model Code as a basic starting point and attempted to achieve acceptability and uniformity. ${ }^{5}$ To accomplish these goals, the Commissioners modified some of the more liberal sections of the Model Code and attempted to phrase the provisions of the Uniform Rules in language familiar to judges and practicing attorneys. However, the Uniform

1 Thayer, A Premimnary Treatise on Evidence at the Common Law 530 (1898) [hereinafter cited as THAYER]. Thayer added that the two leading principles should be: "(1) that nothing is to be received which is not logically probative of some matter requiring to be proved; and (2) that everything which is thus probative should come in, unless a clear ground of policy or law excludes it." Ibid.

2 Moder Code of Evidence (1942). Rule 9 was the key rule of the Model Code and made all cvidence admissible except that which was explicitly excluded for policy reasons. See note 1 supra. Rule 105 gave the trial judge extensive discretion to control the admissibility of evidence and the conduct of the trial.

'See generally Gard, The Uniform Rules of Evidence, 31 Tur. L. REv. 19, 23-24 (1956).

See notes 7, 8 \& 9 infra and accompanying text.

- Gard, supra note 3, at 23; sec Uniform Rules of Evidence, Prefactory Note 161-63. 
Rules retained the Model Code philosophy that all relevant and material evidence should be admitted unless there is a specific rule excluding it. $^{6}$

The Uniform Rules have created a definite, albeit a slow, movement on the part of an increasing number of courts, legislatures and bar associations to consider the adoption of uniform codes of evidence. In fact, the Uniform Rules have been completely adopted in three jurisdictions, ${ }^{7}$ partially adopted in another ${ }^{8}$ and are under serious study elsewhere. ${ }^{9}$ An important aspect of this movement has seen the United States Supreme Court take preliminary steps toward the promulgation of a uniform code of evidence, similar to the Uniform Rules, for use in the federal district courts. ${ }^{10}$ In light

" "Except as otherwise provided in these Rules, (a) every person is qualified to be a witness, and (b) no person has a privilege to refuse to be a witness, and (c) no person is disqualified to testify to any matter, and (d) no person has a privilege to refuse to disclose any matter or to produce any object or writing, and (e) no person has a privilege that another shall not be a witness or shall not disclose any matter or shall not produce any object or writing, and $(f)$ all relevant evidence is admissable." UNIFORM RULE of Evidence 7. As the comment to rule 7 states: "This rule is essential to the general policy and plan of this work. It wipes the slate clean of all disqualifications of witness, privileges and limitations on the admissibility of relevant cvidence. Then harmony and uniformity are achieved by writing back onto the slate the limitations and exceptions desired." The Uniform Rules also provide that the trial judge shall have the discretion to exclude evidence which he feels will consume too much time, lead to prejudice, confuse the issues, or surprise a party. UNIFoRM RULE of EVIDENCE 45.

The Uniform Rules have been adopted almost verbatim by: Kansas, KAN. CoDE of Crv. P. $\$ \$ 60-401$ to -470 (1963); the Panama Canal Zone, 5 C.Z.C. $\$ \S 2731-2996$ (1963); and the Virgin Islands, 5 V.I.C. $\$ \S 771-956$ (1957).

${ }^{8}$ New Jersey has adopted most of the Uniform Rules dealing with privileges. N.J. Stat. 2A: 84A-17-32 (1960).

- New Jersey is considering the Uniform Rules, except those dealing with privileges, see note 8 supra, and adoption of the entire Uniform Rules with some modification is forseeable. Report of the New Jersey Supreme Court Committee on Evidence (1963). California, Oklahoma and Washington are among others giving the Uniform Rules study. The Uniform Rules were proposed for adoption in Utah, Preliminary Draft of the Rules of Evidence, 27 UTAH B. BuLL. 5 (1957), but have met witl opposition among members of the Utah Supreme Court, and their present status is uncertain. Letter from Honorable Dean Sheffeld, Secretary of Utah State Bar, March 12, 1964. For general discussions of the Uniform Rules, see, e.g., Symposium-Minnesota and the Uniform Rules of Evidence, 40 MrN. L. Rev. 297 (1956); How the Adoption of the Uniform Rules of Evidence Would Affect the Law of Evidence in Oregon, 41 ORE. $L$. REv. 273 (1962). A Symposium on the Uniform Rules of Evidence, 10 RUTGERS L. Rev. 479 (1956); The "Uniform Rules" and the California Law of Evidence-A Symposium, 2 U.C.L.A.L. REv. 1 (1954).

${ }^{10}$ See Committee on Rules of Practice and Procedure of the Judicial. Conference of the United States, A Preliminary Report on the Advisibility and Feasibility of Developing Uniform Rules of Evidence for the United STAtes District Courts (1962) (Reported in 30 F.R.D. 73 (1962)) [hereinafter cited as Preliminary Report on Frderar. 
of the latter development this comment will undertake first to provide a general survey of the present status of federal evidence law, and then to analyze and explain the problems facing adoption for use in the federal courts of standardized rules dealing with presumptions.

\section{Federal Evidence Law}

The status of federal evidence law is considered unsatisfactory by many observers. ${ }^{11}$ This condition can in part be attributed to the Conformity Act under which the federal courts were to "conform, as near as may be," to state procedure,,$^{12}$ and to the Rules of Decision Act whereby state decisions are to be followed unless the Constitution or some federal statute provides otherwise. ${ }^{13}$ These acts have had the effect of making federal practice and procedure, and decisional law conform to the law of the state in which the federal court sits. ${ }^{14}$ The Enabling Act of $1934,{ }^{15}$ which purports to give

EvIDENCE RULEs]. The Report suggests that the Uniform Rules might be a model for such rules, $i d$. at 43-48. Several Judicial Conferences of the Circuit Courts and the American Bar Association have urged adoption of uniform rules of evidence for the federal courts. Id. at 1-2. For general articles discussing the adoption of a federal code of evidence see, e.g., Degnan, The Law of Federal Evidence Reform, 76 HARv. L. REv. 275 (1962); Estes, The Need for Uniform Rules of Evidence in the Federal Courts, 24 F.R.D. 331 (1960); Joiner, Uniform Rules of Evidence for the Federal Courts, 20 F.R.D. 429 (1958); Ladd, Uniform Evidence Rules in the Federal Courts, 49 VA. L. REv. 692 (1963); see also 5 Moore, Federat Practice 143.02 (2d ed. 195I).

11 See, e.g., Degnan, supra note 10, at 275-76; Joiner, supra note 10, at 436.

12 Conformity Act of 1872 , ch. 255, $\S \S 5-6,17$ Stat. 197. See generally 5 Moore, Federal Practice If 43.02[2] (2d ed. 1951) [hereinafter cited as Moore]. The Conformity Act was in effect nullified by adoption of the Enabling Act of 1934, 28 U.S.C. $\$ 2072$ (1958); note 15 infra.

13 "The laws of the several states, except where the Constitution or treaties of the United States or Acts of Congress otherwise require or provide, shall be regarded as rules of decision in civil actions in the courts of the United States, in cases where they apply." 28 U.S.C. \$ 1652 (1958). See generally 5 MOORE I 43.02[2]. It seems self evident that if there were a uniform code of evidence for federal courts, the Rules of Decision Act would no longer be applicable.

14 See Degnan, supra note 10, at 278; Morgan, Choice of Law Governing Proof, 58 HaRv. L. REv. 153, 171-72 (1944).

15 "The Supreme Court shall have the power to prescribe, by general rules, the forms of process, writs, pleadings, and motions, and the practice and procedure of the district courts of the United States in civil actions.

"Such rules shall not abridge, enlarge or modify any substantive right and shall preserve the right of trial by jury as at common law and as declared by the Seventh Amendment to the Constitution." 28 U.S.C. $§ 2072$ (1958).

Professor Wigmore has argned that the courts inherently have all the rule-making powers. Wigmore, All Legislative Rules for Judiciary Procedure are Void Constitu. tionally, 23 ILI. L. REv. 276 (1928). However, it seems that the enabling act adds to the Court's inherent power and makes the adoption of evidence rules for the 
the Supreme Court power to adopt rules of "practice and procedure" for the federal courts, in effect allowed for a change in the standard from "conformity" to state law to "uniformity" within the federal court system. Pursuant to this rule-making power, the Court fashioned the Federal Rules of Civil Procedure.

The principal federal rule dealing with evidence is rule 43 (a) which provides for the admissibility in the federal district courts of evidence which would be admitted under the laws of the United States, the rules of evidence in the federal equity courts, or the rules of evidence of the state where the court is sitting. ${ }^{16}$ This rule is concerned entirely with the admissibility of evidence and was viewed by the drafters of the federal rules as a mere stopgap measure until a comprehensive code of evidence could be adopted.17 However, the first steps toward adoption of a code of evidence were not undertaken until the current study, and, as a result, judges and practitioners are presently forced to familiarize themselves with the three systems of evidence enunciated in rule 43 (a). ${ }^{18}$ The situation is further complicated by rule 26 of the Federal Rules of Criminal Procedure which admits evidence according to the federal common law. ${ }^{19}$

district courts more feasible. Sce Joiner, supra note 10, at 433-35. For a general study of the rule-making power in the various states, see Institute of Judicial Administration, Rule Making Power of the Courts 17-20 (Supp. 1958).

${ }^{16}$ Sce gencrally 2B Barron \& Holtzoff, Federal Practice and Procedure \$\$ 961-64, 967,970 (Wright ed. 1961); 5 Moone I 43.02[2] \& [4], I 43.03; Note, The Admissibility of Evidence Under Federal Rule 43(a), 48 VA. L. Rev. 939 (1962). It is gencrally acknowledged that rule 43 (a) applies to both diversity and non-diversity cases. See Ladd, supra note 10, at 696 .

17 See 2B BArron \& Holtzoff, op. cit. supra note 16, § 961, at 207; Prtuminary Report on Federal Evidence Rules 51. The drafters of the federal rules gave some consideration to attacking evidence problems, but decided that such a major undertaking would delay the proposed federal rules and might jeopardize the entire project. See Clark, Foreward, A Symposium on the Uniform Rules of Evidence, 10 RutGers L. REv. 479, 481-82 (1956).

${ }^{18}$ Sce text accompanying note 16 supra.

${ }^{10}$ FED. R. CRIM. P. 26 provides in part that "the admissibility of evidence and the competency and privileges of witnesses shall be governed, by the principles of the common law as they may be interpreted by the courts of the United States in the light of reason and experience." Rule 26 was adopted pursuant to 18 U.S.C. $\$ 3771$ (1958).

Thus, in effect, the judges and trial attorneys must be familiar with four systcms of evidence. "Such overlapping, and at times, conflicting rules, makes trials confused, slows them up, creates ground for argument on appeal, adds to the expense of the trial, and does not promote the rapid dispatch of justice." Joiner, Federal Uniform Evidence Rules, 32 REF. J. I03 (1958). 
The power of the Supreme Court to promote and adopt evidentiary rules for the federal district courts is subject to little or no doubt. The enabling act confers power to prescribe rules of "practice and procedure" and most evidence rules are included in this power. ${ }^{20}$ The only significant limitation on this rule-making power is that rules adopted pursuant to it "shall not abridge, enlarge, or modify any substantive right." 21 The parol evidence rule and conclusive presumptions are generally classified as "substantive" and thus beyond the rule-making power. ${ }^{22}$ While it has been argued that "burden of proof" and privileges may be beyond the rule-making power, it is well established that the vast majority of evidence law can be reformed and codified by the Supreme Court for use in the federal district courts.

The doctrine of Erie R.R. v. Tompkins ${ }^{23}$ presents significant problems in promoting uniformity of evidence law in the federal courts. That case reinforced the "conformity" to state law approach by requiring federal courts in diversity cases to follow the "substantive" law of the forum state. ${ }^{24}$ Thus, even though an evidentiary rule may be within the rule-making power of the Court, it might be "substantive" under the Erie doctrine and inapplicable in diversity cases. The formidable task of determining what is "substantive" and what is "procedural" has produced very uncertain results. In Guaranty Trust Co. v. York ${ }^{25}$ the Supreme Court held that issues should be considered "substantive" if the outcome with regard to those issues significantly affected the result of the litigation. Literally applied, the "outcome determinative" test espoused in Guaranty Trust would inject a far broader meaning into "substantive" than was intended under the enabling act and would render many evidence rules useless in diversity cases. Fortunately the test has not

\footnotetext{
30 Sec Preliminary Report on Federal Evidence Rules 35-36, 48; Degnan, supra note 10, at 277-82; note 15 supra. "The fact that twenty one of the eighty six rules of the Federal Rules of Civil Procedure deal with the subject of evidence shows without question that the draftsmen regarded the rules of evidence as procedural." Ladd, supra note 10, at 696 \& n.l4.

2128 U.S.C. $\$ 2072$ (1958). See note 15 supra.

23 See Preliminary Report on Federal Evidence Rules 39.

${ }^{33} 304$ U.S. 64 (1938).

26 The Erie case particularly gave renewed vitality to the Rules of Decisions Act, 28 L.S.C. \$ 1652 (1958). See Ladd, supra note 10, at 695; note 13 supra.

35326 U.S. 99 (1945).
} 
been used to its full potentia ${ }^{28}$ and, in fact, has been modified by the Supreme Court in Byrd v. Blue Ridge Elec. Co-op. ${ }^{27}$ The Court determined that the federal policy favoring trial by jury should not yield to a contrary state policy merely because the outcome might be affected. However, in stating that it would look at "affirmative countervailing considerations"28 the Court did not repudiate the outcome determinative test and replace it with a policy balancing test. ${ }^{29}$ Notwithstanding the confusion manifested in the Guaranty Trust and Byrd cases concerning the exact effect of Erie, it is fairly well settled that most evidence law is procedural within the meaning of that case and could be adopted for use in the federal courts. ${ }^{30}$

${ }^{20}$ Cf. Hill, The Erie Doctrine and the Constitution, 53 Nw. U.L. REv. 427, 437 (1958); Smith, Blue Ridge and Beyond: A Byrd's-Eye View of Federalism in Diversity Litigation, 36 TuL. L. Rev. 443, 446 (1962). A further indication of the above conclusion is the fact that the federal rules have been held almost entirely beyond the scope of Erie.

27356 U.S. 525 (1958). See generally Preliminary Report on Federal Evidence RULES 37; I BARRON \& HOLTZOFF, op. cit. supra note 16 , at $\S 138$.

28356 U.S. at 537.

20 The Court in Byrd merely provided that in instances where there was a countervailing federal policy, that policy would be taken into consideration. See Smith, supra note 26, at 449-53; Vestal, Erie R.R. v. Tomkins: A Projection, 48 IowA L. Rev. 248, 271 (1963). One commentator has criticized the current study for placing too heavy a reliance upon Byrd. Degnan, supra note 10 , at $290-99$.

Several lower courts have taken comfort from Byrd in making extensive use of the illusory rules of evidence in federal equity courts to admit evidence under rule 43 (a). See, e.g., Hope v. Hearst Consol. Publications, Inc., 294 F.2d 681 (2d Cir. 1961), cert. denied, 368 U.S. 956 (1962); Monarch Ins. Co. v. Spach, 281 F.2d 401 (5th Cir. 1960); see also text accompanying note 16 supra. The current federal study places considerable rehance on Monarch. See Preliminary Report on Federal Evidence Rules 37. At least one treatise has given full support to Monarch. See 2B BARRON \& HoLTzOFF, op. cit. supra note 16, at \$ 962. See generally Comment, Federal Rule 43(a): The Scope of Admissi. bility of Evidence and the Implications of the "Erie" Doctrine, 62 Cocum. L. REv. 1049 (1962).

so "Rules of evidence should be treated within the domain of procedural law." 5 MOore If 43.02[2], at 1310; see also Morgan, Rules of Evidence-Substantive or Procedural?, 10 VAND. L. REV. 467 (1957).

The full force and effect of the Erie doctrine will remain unknown until the Supreme Court determines whether that doctrine is based on a policy or a constitu* tional requirement. The "affirmative consideration" test enunciated in Byrd and the use of a policy balancing approach in some lower courts, note 29 supra, scems to furtler necessitate an answer to the above question. See Smith, supra note 26, at 465-70. For articles supporting the view that Erie is constitutionally required, see, e.g., Hart, The Relations Between State and Federal Law, 54 Colvm. L. REv. 489, 509-10 (1954); Hill, supra note 26, at 437-38. But see, e.g., Clark, State Law in The Federal Courts: The Brooding Omnipresence of Erie v. Tompkins, 55 YALE L.J. 267, 278-79 (1946); Currie, Change of Venue and the Conflict of Laws, 22 U. CHI. L. REv. 405, 468-69 (1955); Kurland, Mr. Justice Frankfurter, The Supreme Court and the Erie Doctrine in Diversity Cases, 67 YALE L.J. 187, 188-204 (1957). 


\section{Presumptions}

Presumptions is an area in which it will be particularly difficult to promulgate a uniform code of evidence for the federal district courts. In considering adoption of the Uniform Rules with regard to presumptions for use in the federal courts, two problems will have to be given special attention: are the rules subject to the strictures of Erie and thus controlled by state law in diversity cases; and are they substantive within the meaning of the enabling act and thus beyond the rule-making power of the Supreme Court?

The problems created by presumptions led Professor Thayer to remark that "among things so beset with ambiguity there is abundant opportunity for him to stumble and fall who does not pick his way and walk with caution." 31 In light of the attendant difficulties some effort will be expended at this point to explain the workings of presumptions before considering the unique problems that will be encountered in framing rules for their use in the federal courts.

\section{Workings of Presumptions}

Much of the confusion concerning presumptions has resulted because they are inextricably intertwined with "burden of proof." In fact, a presumption can properly be defined as a vehicle for distributing the "burden of proof" among the parties. Thayer first clearly enunciated the dissection of burden of proof that was adopted by the Uniform Rules. ${ }^{32}$ Under this analysis, burden of proof is divided into burden of persuasion and burden of producing evidence. The burden of persuasion requires the party upon whom this burden rests to convince or persuade the jury by a certain quantum of evidence that a certain fact exists or does not exist. ${ }^{33}$

a1 Thayer 352. Professor Morgan has stated that "every writer of sufficient intelligence to appreciate the difficulties of the subject matter has approached the topic of presumptions with a sense of hopelessness and has left it with a feeling of despair." Morgan, Presumptions, 12 WAst. L. REv. 255 (1937).

32 Thayer 355.64. The definitional problem is particularly confusing because "there is an undiscriminating use of the phrase [burden of proof], perhaps more common than either of the other two [burden of persuasion and burden of producing evidence], in which it may mean either or both of the others." Id. at 355.

33 "'Burden of Proof' means the obligation of a party to meet the requirements of a rule of law that the fact be proved either by a preponderance of the evidence or by clear and convincing evidence or beyond a reasonable doubt, as the case may be. Burden of proof is synonymous with "burden of persuasion." UNIFORM RulE of EvIDENCE 1 (4). New Jersey has adopted this definition. N.J. Stat. 2A:84A-5 (1961). In this comment the term "burden of persuasion" will be used in an effort to avoid confusion of terms. See note 32 supra. For an interesting and strongly argued view 
The burden of producing evidence requires only that the party upon whom it rests introduce some evidence or suffer the risk of a directed verdict or a peremptory instruction to the jury. ${ }^{34}$ Considerable dispute has arisen as to whether a presumption "places"'35 either or both of the "burdens of proof" upon the party against whom it operates.

A presumption is defined in rule 13 of the Uniform Rules as a rule of law which requires that one fact, the presumed fact, be assumed when another fact, the basic fact, is established. ${ }^{30}$ Although it rests upon the basic fact, the presumption is not dependent upon a process of inference and is not evidence to be considered by the jury. ${ }^{37}$ The basic fact may be established in several ways. ${ }^{38}$ However,

that burden of persuasion should be expressed in terms of degree of belief rather than "preponderance," "clear and convincing" and "reasonable doubt," see McBaine, Burden of Proof: Presumptions, 2 U.C.L.A.L. REv. 13 (1954); see also McBaine, Burden of Proof: Degree of Belief, 32 CaLIF. L. Rev. 242 (1944).

s4 " 'Burden of producing evidence' means the obligations of a party to introduce evidence when necessary to avoid the risk of a directed verdict or peremptory finding against him on a material issue of fact." UNIForm Rule of Evidence 1 (5). New Jersey has adopted the essence of this rule. N.J. Stat. ANN. 2A:84A.6 (Supp, 1963).

${ }_{35}$ The courts and legal writers normally use the word "shifts." This comment will employ the term "places," since it more nearly expresses the actual operation of a prcsumption, particularly with reference to the burden of persuasion. In fact, the burden of persuasion does not come into play until after all the evidence has been presented. See McCormick, LAW of Evidence 639 (1954) [hereinafter cited as McCormick].

so "A presumption is an assumption of fact resulting from a rule of law which requires such fact to be assumed from another fact or group of facts found or otherwise established in the action." UNIFORM RULE of Evidence 13. This definition was adopted by the Utah Supreme Court in In the Matter of Estate of Swan, 4 Utah 2d 277, 289 n.15, 293 P.2d 682, 690 n.15 (1956). Uniform Rule 13 is sufficiently broad to include the "conclusive" or "irrebuttable" presumption, which is not in faet a presumption but a rule of substantive law. Morgan, Maguire \& WEInstein, Evidence 439 (4th ed. 1957); 9 Wigmore § 2492; Brosman, The Statutory Presumption, 5 Tul. L. Rev. 17, 24 (1930). Since the only "true" presumption is a rebuttable one and the other Uniform Rules apply only to rebuttable presumptions, it might be wise to put the words "a rebuttable" before the word "assumption" in Uniform Rule 13. See REPORT or THE New Jersey Supreme Court Commitree on Evidence 45 (1963). By the use of the word "requires" the above definition excludes inferences, which should not be confused with presumptions. "The distinction is between a matter of logic and experience [inference] and a rule of law [presumption]." Gausewitz, Presumptions, 40 MinN. L. Rev. 391, 392 (1956).

${ }^{37}$ See note 36 supra. The rule that a presumption is not evidence is a long standing rule which is not seriously disputed, at least in the federal courts. Sce Agnew v. United States, 165 U.S. 86 (1897), limiting Coffin v. United States, 156 U.S. 432 (1895) ("presumption" of innocence) discussed in Harrell v. United States, 220 F.2d 516, 522 (5th Cir. 1955); Jefferson Standard Life Ins. Co. v. Clemmer, 79 F.2d 724 (4th Cir. 1935) (presumption against suicide); Tyrrell v. Prudential Ins. Co., 109 Vt. 6, 192 Atl. 184 (1937); Levin, Pennsylvania and the Uniform Rules of Evidence: Presumptions and Dead Man Statules, 103 U. PA. L. REv. 1, 14 (1954); McBaine, Presumptions: Are They 
in those instances where the jury must decide if there is sufficient evidence to establish the basic fact, problems in framing instructions can result. ${ }^{30}$ Nonetheless, the judiciary or the legislature decides whether a certain basic fact will justify assumption of the presumed fact; the jury merely decides whether or not the proponent of the presumption has offered sufficient evidence to establish the basic fact. Several grounds for permitting the basic fact to support the presumed fact have been recognized by the courts. ${ }^{40}$ Although probability or logical connection between the basic fact and the presumed fact has undoubtedly been the greatest single factor in the recognition of presumptions, it must be remembered that they do not arise by a process of inference. Presumptions are primarily devices for distributing the "burdens of proof" and are only secondarily aids to reasoning. The Supreme Court has apparently not recognized the above distinction and has saddled the courts with a test requiring a "rational connection" between the basic and presumed facts when adjudicating the constitutionality of statutory presumptions. ${ }^{41}$

Evidence?, 26 Caljf. L. Rev. 519 (1938). But see I Grdenlear, Evidence $\$ 34$ (1842); Smellie v. Southern Pac. Co., 212 Cal. 540, 299 Pac. 529 (1931). Nonetheless, the jury is free to draw the normal inferences from the basic fact, if established, whether or not the presumed fact has been assumed. THAYER 545; MCCormick 650-52; Morgan, Instructing the Jury Upon Presumptions and Burden of Proof, 47 HARv. L. REv. 59, 69 (1933).

${ }^{38}$ The basic fact can be established by the pleadings, by stipulation of the parties, by judicial notice or by the production of sufficient evidence. UNIFORM RULE of EvIDENCE 13, comment; Model Code of Evidence rule 702 (1942); Morgan, The Law of Evidence, 1941-1945, 59 HARv. L. REv. 481, 495 (1946).

${ }^{30}$ The judge must instruct the jury that, if it finds there is sufficient evidence to establish the basic fact, then the presumed fact must be assumed; and if there is not sufficient evidence to establish the basic fact then the jury is to forget about the presumed fact. Most authorities agree with Judge Learned Hand that "if the trial is properly conducted, the presumption will not be mentioned at all." Alpine Forwarding Co. v. Pennsylvania R.R., 60 F.2d 734, 736 (2nd Cir. 1932). See Morgan, supra note 31, at 281; Morgan, supra note 37. Contra, McCoRMick 663-72; Reaugh, Presumptions and the Burden of Proof, 36 ILL. L. REv. 819, 830-48 (1942).

4 Four grounds are: probability or logical connection; peculiar knowledge or access to evidence; procedural convenience; and social and economic policy. See McCoRMICK 641; Morgan, Maguire \& Weinstein, op. cit. supra note 36 , at $440-43$.

"I "Under our decision, a statutory presumption cannot be sustained if there be no rational conneetion between the fact proved and the ultimate fact presumed ...." Tot v. United States, 319 U.S. 463, 467 (1943). (Emphasis added.) Western \& Atl. R.R. v. Fenderson, 279 U.S. 639, 643-44 (1929); Mobile, Jackson \& K.C.R.R. v. Turnipseed, 219 U.S. 35, 43 (1910). This test, at least in the context of civil cases, unduly restricts the work of the presumption and in effect makes them inferences. Tot was a criminal case, and most writers relying to a large degree on dictum in Morrison v. California, 291 U.S. 82, 90-91 (1934), have attempted to limit the effect of Tot to the criminal sphere where there is some basis for the test. However, the test is one that 
The above definition of a presumption as a rule of law requiring that the presumed fact be assumed from the basic fact is generally agreed upon by courts and commentators. They also agree that the presumed fact must be accepted as true until the party against whom the presumption operates has introduced rebutting evidence to show the non-existence of the presumed fact. ${ }^{42}$ However, at this juncture agreement ends and confusion, chaos and conflict begin. One major disagreement concerns what quantum of evidence of the non-existence of the presumed fact must be introduced to rebut the presumption. Also, statements as to the effect to be given presumptions are as varied as the number of courts which have attempted this Sisyphean feat. ${ }^{43}$

will continue to give trouble until the Court clearly articulates its scope. In fact, the rational connection test led to Uniform Rule 14 (b). See generally McCoRMick 654.63; Morgan, Tot $v$. United States: Constitutional Restrictions on the Statutory Presump. tions, 56 HARv. L. REv. 1324 (1943); Note, Constitutionality of Rebuttable Stattitory Presumptions, 55 Colum. L. REv. 527 (1955). For a good general discussion of statutory presumptions see Brosman, The Statutory Presumption (pts. 1 \& 2), 5 TuL. L. REv. 17, 178 (1930-31).

29 Wigmore § 2491; Gausewitz, supra note 36, at 393; Morgan, Presumptions, 10 RutGers L. REv. 512, 516 (1956); Morgan, Further Observations on Presumptions, 16 So. CAL. L. REv. 245, 246-47 (1943).

$\$ 3$ "Perhaps no topic of the law has perplexed the courts more than the scope and effect of legal presumptions. The complexities and subtleties of the subject, enhanced no doubt by the variant theories regarding them and the confusion of thought manifested in the discussion of the questions incident to them, have given rise to a condition that has been characterized as 'a welter of loose language and discordant decisions.' " Tyrrell v. Prudential lns. Co. of America, 109 Vt. 6, 22, 192 Atl. 184, 191 (1937). (Emphasis added.)

Professor Morgan has found eight effects that courts have accorded presumptions. of the eight, Morgan and others have given serious consideration to three. Undcr the first of these views, the mere introduction of evidence which would justify a finding of the nonexistence of the presumed fact dissipates the presumption. This is the Thayer-Wigmore rule adopted by the Model Code. See notes 44.48 infra and accompanying text. This approach was adopted in Uniform Rule I4(b) for presumptions where the basic fact has no probative value as to the existence of the presumed fact. See notes 53 \& 54 infra and accompanying text. The second view holds that the artificial effect remains unless evidence of the non-existence of the presumed fact convinces the jury that its non-existence is at least as probable as is its existence. Morgan rejected this approach as too confusing, but Professor McBaine argues that this is the proper view. McBaine, Burden of Proof: Presumptions, 2 U.C.L.A.L. REv. 13 (1954). The third view is similar to the second and differs only in that the artificial effect remains until the jury is convinced that the non-existence is more probable than its existence. This is the so called "Pennsylvania rule" which Morgan supported and which was adopted in Uniform Rule 14 (a) for presumptions where the basic fact has some probative value of the presumed fact. See notes 51 \& 52 infra and accompanying text. For a good discussion of the "Pennsylvania rule" and the present law of presumptions in Pennsylvania, see Levin, supra note 37, at 12-20. Actually Morgan suggested the combination of the first and third views discussed above that was 
The classic definition of the function of a presumption was articulated by Thayer ${ }^{44}$ and evangelized to the legal community by Wigmore. ${ }^{45}$ Under this approach, a presumption fixes the burden of producing evidence upon the party against whom it operates and "this alone, appears to be characteristic and essential work of a presumption." $4 \mathrm{~b}$ The presumption will be successfully rebutted by the introduction of any evidence which is sufficient to support the non-existence of the presumed fact. ${ }^{4 \pi}$ In effect, the presumption requires the party against whom it operates to introduce sufficient evidence to avoid a directed verdict. The Thayer-Wigmore theory was adopted by the drafters of the Model Code ${ }^{48}$ over a strong protest.

The protesters, lead by Professor Morgan, argued that under the Thayer-Wigmore theory a presumption is an anomaly, for it is strong enough to determine the outcome of an entire case, yet completely disappears with the introduction of evidence which reasonable men could disbelieve. ${ }^{49}$ Morgan proposed that a presumption should have the effect of placing the burden of persuasion of the issue

adopted in Uniform Rule 14. Morgan, Some Observations Concerning a Model Code of Evidence, 89 U. PA. L. REv. 145, 162-63 (1940). See generally Morgan, supra note 31, at 259-71; Morgan, Techniques in the Use of Presumptions, 24 lowa L. Rev. 413, 417 (1939).

“THAYER 313-52.

¿ 9 WIGMORE $\$ \S 2487,2491$.

40 Thayer at 337.

47 "The evidence to overcome a presumption must be credible, substantial, sufficient to support a finding..." Cleary, Presuming and Pleading: An Essay on Juristic Immaturity, 12 StaN. L. REv. 5, 18 (1959). See Jefferson Standard Life Ins. Co. v. Clemmer, 79 F.2d 724, 729 (4th Cir. 1935). However, this evidence need not be believed by the judge who determines whether or not the presumption has been rebutted. Some courts, in an effort to give the presumption added strength, have asked the jury to judge the credibility of the evidence and to render this decision. See, e.g., O'Dea v. Amodeo, 118 Conn. 58, 170 Atl. 486 (1934). It is submitted that such a task is conceptually difficult and unduly confuses the jury.

${ }^{4}$ MOdEL CODE OF EvideNCE rules 701-04 (1942); see generally Laughlin, The Location of the Burden of Persuasion, 18 U. P1Tr. L. REv. 3 (1956); Laughlin, In Support of the Thayer Theory of Presumptions, 52 Mrch. L. REv. 195 (1953). See Morgan, Further Observations on Presumptions, 16 So. CAL. L. REv. 245, 259 (1943), where the author gives lukewarm support to the Model Code approach to presumptions.

${ }^{10}$ At the 1941 meeting of the American Law Institute, Morgan stated: "What I object to in the Thayerian rule is this: the creation of the presumption for a reason that the court deems sufficient, a rule of law if this basic fact stands by itself there must be a finding of a presumed fact, whether the jury would ordinarily find it from the basic fact or not; but then the total destruction of the presumption just the minute some testimony is put in which anybody can disbelieve, which comes from interested witnesses, and which is the sort that is usually disbelieved." 18 AMERICAN LAw Institute Proceedings 221 (1941). 
under consideration upon the party against whom it operates. ${ }^{50}$ This approach was taken by the drafters of the Uniform Rules and effectuated one of the most drastic departures from the Model Code.

Rule 14 of the Uniform Rules contains the essence of Morgan's theory. Under rule 14 (a), if the basic fact has some logical value in proving the presumed fact, "the burden of establishing the nonexistence of the presumed fact is upon the party against whom the presumption operates."51 The phrase "burden of establishing," although nowhere defined, undoubtedly means the burden of persuading the jury of the non-existence of the presumed fact by a preponderance of the evidence. ${ }^{52}$ Rule 14 (b) limits the effect to be accorded a presumption in those few instances where the basic fact has no logical value in proving the presumed fact. ${ }^{53}$ In such in-

\footnotetext{
${ }^{\circ}$ As reporter for the Model Code, Morgan proposed that such a view be adopted by the Model Code. Morgan, Forward, Model Code of Evidence 57 (1942). However, the recommendation made by Morgan and the advisory committee was rejected by the members of the American Law Institute in favor of the Thayer-Wigmore theory after extensive debate. 18 Amierican Law Institute Proceedings 197-228 (1941).

Morgan was not the first commentator to advocate a departure from strict reliancc on the Thayer-Wigmore view. See Bohlen, The Effect of Rebuttable Presumptions of Law upon the Burden of Proof, 68 U. PA. L. REv. 307 (1920); Chafee, The Progress of the Law, 1919-1921: Evidence, 35 Harv. L. REv. 302, 313 (1922). However, it was not until Morgan wrote the first of his many articles on presumptions that the ThayerWigmore doctrine came under sustained attack. See Morgan, Some Observations Concerning Presumptions, 44 HARv. L. REv. 906 (1931); sce also Morgan, stlpra note 37; Morgan supra note 31; Morgan \& Maguire, Looking Backward and Forward at Evidence, 50 HaRv. L. Rev. 909 (1937). For almost a decade Morgan urged a strict "Pennsylvania rule" (see note 43 supra) approach to presumptions, but in 1939 he suggested that a combination of this view with the Thayer-Wigmore rule might bc appropriate. Morgan, Techniques in the Use of Presumptions, 24 Iows L, Ruv. 413, 435 (1939). Under the latter proposal the Thayer-Wigmore rule would be used where the basic fact had no value in proving the presumed fact, while the "Pennsylvania rule" would be employed where the basic fact had probative value of the presumed fact. Morgan, Some Observations Concerning a Model Code of Evidence, 89 U. PA. L. Rev. 145, 162-63 (1940); 18 Amierican LAW INstitute Proceedings 199-200 (1941). Although rejected by the drafters of the Model Code, this latter approach was adopted in Uniform Rule 14. See notes 51 \& 52 infra and accompanying text; Morgan, Presumptions, 10 Rutgers L. Rev. 512 (1956). See generally Helman, Presumptions, 22 GAN. B. REv. 118 (1944).

61 "Subject to Rule 16, and except for presumptions which are conclusive or irrefutable under the rules of law from which they arise, (a) if the facts from which the presumption is derived have any probative value as evidence of the existence of the presumed fact, the presumption continues to exist and the burden of establishing the non-existence of the presumed fact is upon the party against whom the presumption operates..." UNIFORM RULE of Evidence 14(a). See generally Levin supra note 37, at 20-24; Morgan, Presumptions, 10 Rutcers L. Rev. 512 (1956).

52 Morgan, supra note 51, at 513-14. But see McBaine, supra note 43, at 24-28.

53 "Subject to Rule 16, and except for presumptions which are conclusive or irref-
} 
stances only the burden of producing evidence is placed upon the opponent, thus avoiding some of the difficulties created by rule 14 (a) when there is no such "rational connection."54

Uniform rule 16, which should be read in conjunction with rule 14, makes clear that extraordinary presumptions "shall not be affected by Rules 14 or 15 and the burden of proof [persuasion] to overcome it continues on the party against whom the presumption operates." 55 The prime example is the presumption of legitimacy, which is easy to attack, but which, for sound policy reasons, falls only in the face of the most convincing evidence. ${ }^{50}$

utable under the rules of law from which they arise, ... (b) if the facts from which the presumption arises have no probative value as evidence of the presumed fact, the presumption does not exist when evidence is introduced which would support a finding of the non-existence of the presumed fact, and the fact which would otherwise be presumed shall be determined from the evidence exactly as if no presumption was or had ever been involved." UNIFORM RULE of EVIDENCE 14 (b).

s4 See Morgan, supra note 51, at 513; notes 41, 43 \& 50 supra. Model Code of Evidence rule 704, comment at 314 (1942), indicates that the drafters of the Model Code felt the Thayer-Tigmore approach to presumptions would avoid the constitutional difficulties created by Western \& Atl. R.R. v. Henderson, 279 U.S. 639 (1929) and Mobile, Jackson \& K.C.R.R. v. Turuipseed, 219 U.S. 35 (1910). This is precisely the reason that Morgan shifted from a pure "Pennsylvania rule" approach and urged a combination of that rule with the Thayer-Wigmore theory. 18 American Law Institute ProceedINGs 206-07, 222 (I94I); see note 50 supra.

For a proposal that no distinction be drawn on the basis of rational connection between the basic and presumed fact, see Report of THE New JERSEy Supreme Court Commitee on Evidence 50 (1963). The New Jersey committee urged that Uniform Rule 14 (b) creates needless confusion and recommended that it be disregarded. It is submitted that such an approach, although possibly theoretically satisfying, ignores the present status of the law. See Tot v. United States, 319 U.S. 463 (1943); note 41 supra.

s5 "A presumption, which by a rule of law may be overcome only by proof beyond a reasonable doubt, or by clear and convincing evidence, shall not be affected by Rules 14 or 15 and the burden of proof to overcome it continues on the party against whom the presumption operates." UNIFORM RULE OF EvIDENCE 16.

50 The comment to Uniform Rule 16 indicates that the so called presumption of innocence is not to be disturbed by Uniform Rules 13-15. Since the state always has the burden beyond a reasonable doubt in a criminal case, that presumption is mere surplusage. See, e.g., 9 WIGMORE $\S 2511$.

Uniform Rule 15 provides that when the basic facts of two inconsistent presumptions are established "the judge shall apply the presumption which is founded on the weightier consideration of policy and logic. If there is no such preponderance both presumptions shall be disregarded." Under the pure Thayer-Wigmore theory, inconsistent presumptions are said to always cancel one another. 9 Wigmore $\$ 2493$. One report has suggested that the last sentence of Uniform Rule 15 be omitted and that the jury be instructed as to both presumptions if they are equally balanced. REPORT of the Nety Jersey Supreme Court Committee on Evidence 51-52 (1963). It is submitted that such a rule would unduly complicate the judge's function and might lead to some very confusing jury instructions. 


\section{Rules for the Federal Courts}

In this section special attention will be given to the very real problems facing adoption of the Uniform Rules approach to presumptions for use in the federal district courts. In addition, the Thayer-Wigmore approach will be analyzed to determine if that theory might prove more acceptable and feasible for use in the district courts. Finally, certain general conclusions based upon this analysis will be set forth as to what rules for presumptions might be adopted in the federal courts.

In the preceding discussion of the operation of presumptions, it was stated as a general rule that a presumption "is not evidence to be considered by the jury." ${ }^{2} \mathrm{t}$ Unfortunately, not all courts adhere to this view, as is illustrated by a recent federal court case wherein an issue was whether a state presumption of accidental death was evidence to be weighed by the jury. ${ }^{58}$ In upholding the district court's application of the state rule that the "presumption" was to be accorded the status of evidence, the Supreme Court stated that "under the Erie rule, presumptions (and their effects) and the burden of proof are 'substantive...." "5s Since the Court accepted the view that the "presumption" involved was to be accorded an artificial status as evidence, the holding that it was substantive within the meaning of Erie is understandable. As evidence the "presumption" could affect both the outcome of the litigation and a substantial state policy.00

Since the Uniform Rules approach to presumptions gives them the appearance of evidence, ${ }^{61}$ doubts might be raised as to the effect

\footnotetext{
${ }^{87}$ See note 37 supra and accompanying text.

${ }^{88}$ Dick v. New York Life Ins. Co., 359 U.S. 437 (1959). In Dick an action to recover under a double indemnity clause was instituted in a North Dakota state court and removed to the federal court on grounds of diversity of citizenship. The district court rejected an argument that it should apply the Thayer-Wigmore theory, id. at 443 n.4, and instead applied the North Dakota rule enunciated in Svikovec v. Woodman Acc. Co., 69 N.D. 259, 264, 285 N.W. 447, 449 (1939), which gives "the presumption in favor of accidental death the weight of affirmative evidence." The law of presumptions in North Dakota is confused in part because of an archaic statute. N.D. CODE ANN. 31-11-01 to -03 (1960). California, Montana, Nevada and Oregon have similar statutory provisions.

${ }^{s 0} 359$ U.S. at 446.

${ }^{\circ 0}$ See New York Life Ins. Co. v. Gamer, 303 U.S. 161 (1938), where the Court refused to apply the Montana rule that presumptions are evidence and held that "the presumption is not evidence and may not be given weight as evidence." Id. at 171.

61 "[T] $[$ he presumption continues to exist and the burden of establishing the nonexistence of the presumed fact is upon the party against whom the presumption
} 
of the Erie doctrine in diversity cases. This resemblance to evidence is caused primarily by the fact that the Uniform Rules presumption places the burden of persuasion upon the party against whom it operates. Morgan, faced with the long standing rule that a presumption is not evidence, ${ }^{62}$ has argued that in almost all cases the jury will be persuaded one way or the other and that it really does not matter who has the burden of persuasion. Thus, Morgan argues, the Uniform Rules presumption is merely a rule of procedure which determines the outcome of litigation only when the jury is in equilibrium. ${ }^{63}$ However, it is submitted that such an argument involves a mere play on words, for when a presumed fact must be overcome by a preponderence of the evidence to be rebutted, it clearly has the effect of evidence whatever the nomenclature one uses to designate it. ${ }^{6 t}$ Thus, Morgan's argument appears to be subject to doubt and the Uniform Rules presumption might well be termed "substantive" within the meaning of Erie.

Furthermore, the Supreme Court has explicitly held that "burden of proof," at least in the sense of the burden of persuasion, is substantive within Erie. ${ }^{65}$ Thus, whether or not the Uniform Rules

operates..." UNIform RuLEs of Evidence 14 (a). Professor McBaine argues that such a rule is not the equivalent of making a presumption evidence, because presumptions "may be given sufficient force and vitality to survive against contrary evidence that the jury does not believe." McBaine, supra note 37, at 548. McBaine seems to feel that the jury will be able to look only at the rebutting evidence and determine ou the basis of the credibility of that evidence whether or not the presumption has been dissipated. Although this may be a theoretically sound argument, it is submitted that the jury will, in fact, weigh the presumed fact as evidence against the rebuttal evidence in determining whether or not the presumption has been rebutted.

Q2 See note 37 supra.

03 "If the jury is satisfied either way, it makes no difference who has the burden of persuasion, but when the mind of the jury... is in equilibrium, then the party having the burden of persuasion loses; so that the most effect that this gives to a presumption when evidence is introduced contrary to it is the effect which a piece of evidence would have that would throw the case out of equilibrium...." 18 AMERICAN LAW INSTITUTE Proceedings 221 (1941). (Emphasis added.)

on "It is sometimes said that the presumption will tip the scale when the evidence is balanced. But, in truth, nothing tips the scale but evidence, and a presumptionbeing a legal rule or a legal conclusion-is not evidence." THAYER 576 (Storrs Lecture 1896). This language was quoted with approval in the leading case of Watkins v. Prudential Ins. Co. 315 Pa. 497, 503, 173 Atl. 644, 647 (1934), Annot., 95 A.L.R. 869 (1935). See generally Bernstein, The Presumption of Due Care-An Analysis, $20 \mathrm{PA}$. B. Ass'N Q. 24, 29-30 (1948).

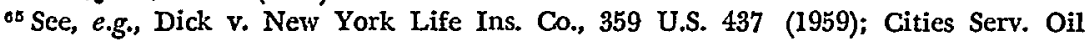
Co. v. Dunlap, 308 U.S. 208 (1939), 88 U. PA. L. Rev. 482 (1940) (approving), 18 TexAs L. Rev. 226 (1940) (disapproving); Desjardins v. Desjardins, 308 F.2d 111, 116 n.3 (6th Cir. 1962); 2B Barron \& Holtzoff, Federal Practice and Procedure $\$ 964$ 
presumption is "evidence," the fact that it affects the placing of the burden of persuasion would make its application to diversity cases unlikely. ${ }^{66}$ Obviously, the placing of this burden is of great practical consequence, and anything during the trial which might cause it to be placed upon a different party could affect the outcome and a substantial state policy. Indeed, the burden of persuasion is so well established as being "substantive" within Erie that the Uniform Rules approach to presumptions could not be used by the federal courts in diversity cases.

This raises the question whether the Uniform Rules approach makes the presumption "substantive" within the meaning of the enabling act. ${ }^{67}$ If not, then possibly the Uniform Rules approach could be adopted and applied in nondiversity, criminal, and admiralty cases, and thereby effectuate at least a partial unification. ${ }^{08}$ While "substantive" as used in the enabling act does not have the same meaning it has in Erie, there is no precise definition of what is subsumed within the statutory usage of the term. To say that the term means that which is not procedural merely begs the question.

(1961); 5 Moore T 43.08. In the Preliminary Report on Federal Evidence Rules 39, it was noted that "certain other matters usually treated under the law of evidence, have been held to be so far substantive as not to be within the rulc-making powcr, for example, burden of proof." The Report was not explicit in how it was using "burden of proof," but apparently burden of persuasion was the meaning intended.

-There are some presumptions "which shift the burden of proof and since as noted above burden of proof [burden of persuasion] is substantive such state created presumptions must be applied in non-federal cases." 5 MOore I 45.03, 1337-38. Dean Ladd recently remarked that under the Uniform Rules "rebuttable presumptions derived from facts having any probative value shift the burden of proof [burden of persuasion] to the party against whom the presumption operates to establish the nonexistence of the presumed fact. The Erie case would probably control and in diversity cases prevent the use of a presumption contrary to state law." Ladd, Uniform Evidence Rules in the Federal Courts, 49 VA. L. REv. 692, 698 (1963).

${ }^{67} 28$ U.S.C. $\$ 2072$ (1958). See note 15 supra. See also 18 U.S.C. $\$ \$ 3771-72$ (1958) (criminal procedure), 28 U.S.C. $\$ 2073$ (1958) (admiralty procedurc).

${ }^{\circ}$ See note 67 supra. "[E]ven though the Erie doctrine applies in federal civil actions and causes trouble there as to uniform rules of evidence, it does not apply in criminal or in admiralty cases." Orfield, Uniform Federal Rules of Evidence, 67 Dick. L. REv. 381, 386 (1963). This approach has merit in light of the fact that of the civil cases instituted in I962 in the federal district courts (not including land condemnations, District of Columbia insanity, and local jurisdiction cases), only about onc third were diversity cases. (Diversity-34.8\%, United States-37.6\%, Federal Question$24.9 \%$ ). Yet, when the criminal cases are included diversity cases account for only about one fourth of the cases brought to the trial stage. (Diversity-26.7\%, Unitcd States$11.5 \%$, Federal Question-12.7\%, Criminal-49.1\%). DIR. OF Adm. OfFICE OF U.S. Courts ANn. ReP. 104-II (1962). See Degnan, The Law of Federal Evidence Reform, 76 HARv. L. REv. 275, 287 (1962), where the author questions the wisdom of adopting rules if diversity cases cannot be included. 
However, it is submitted that a rule which affects an element as important to a case as the positioning of the burden of persuasion goes beyond what legitimately can be called procedural and affects the substantive rights of the parties. ${ }^{89}$ Although federal rule 8 (c) has successfully been attacked as "substantive" within Erie for placing the burden of persuasion of certain defenses upon the defendant, ${ }^{70}$ it has not been declared to be beyond the Supreme Court's rulemaking power. ${ }^{71}$ While this fact could be urged as grounds for the adoption of the Uniform Rules approach, such an argument can be questioned. One possible distinction is that federal rule 8 (c) determines where the burden of persuasion rests before the trial begins, while the Uniform Rules presumption can cause that burden to be placed upon a different party while the trial is in progress. Thus, the Uniform Rules presumption is arguably "substantive" within the meaning of the enabling act and beyond the rule-making power of the Court. ${ }^{2}$

Since the Uniform Rules definition of the effect of a presumption will have to be abandoned for use in the trial of diversity cases and might have to be abandoned for non-diversity cases, the ThayerWigmore theory should be considered for adoption in the federal courts. ${ }^{73}$ Even Morgan has acknowledged that the Thayer-Wigmore approach is the only logical alternative to the Uniform Rules. ${ }^{74}$

${ }^{\circ 0}$ But see Degnan, supra note 68, at 283 n.35; Ladd, supra note 66, at 698, n.20.

${ }^{70}$ See 2 MOORE I 8.27[2]. In Francis v. Humphrey, 25 F. Supp. (E.D. Ill. 1938), the court rejected plaintiff's argument that the placing of the burden of proving contributory negligence was a matter of procedure and held "that the absence of contributory negligence is made an essential part of the plaintiff's cause of action by the substantive law of Illinois and this substantive rule, declared by the courts of Illinois, must be recognized and followed by the federal courts." Id. at 5. In Palmer v. Hoffman, 318 U.S. 109, 117 (1943), the Supreme Court stated that "Rule 8(c) covers only the manner of pleading. The question of the burden of establishing contributory negligence is a question of local law which federal courts in diversity of citizenship cases . . must apply."

${ }^{21}$ Apparently federal rule 8 (c) is still applicable in non-diversity cases. See Willie v. Harris County, 202 F. Supp. 549, 552-53 (S.D. Tex., 1962), where the court stated that "this line of reasoning [no state action] assumes the characteristics of an affirmative defense, which must be both pleaded and proved with particularity."

${ }^{72}$ See text accompanying note 69 supra.

${ }^{73}$ After stating that Erie "would probably control" the Uniform Rules approach to presumptions in diversity cases, Dean Ladd noted that "if the rules would be like those in the Model Code of Evidence [rule 704] which cause a presumption to disappear as soon as rebutting testimony is introduced, an opposite result could be possible." Ladd, supra note 66, at 698.

"Morgan, Techniques in the Use of Presumptions, 24 Iowa L. Rev. 413, 435 (1939). See also Morgan, Further Observations on Presumptions, 16 So. CaL. L. Rev. 245, 265 (1943), where the author stated that "although not giving complete rational satisfaction, 
Moreover, a review of the cases reveals that, in almost all instances where presumptions have been held substantive within the meaning of Erie, they were either accorded the status of evidence, ${ }^{75}$ or "burden of proof" was used in the sense of burden of persuasion..$^{70}$ In fact, if there is presently a rule for presumptions in the federal courts, it is very close to the Thayer-Wigmore approach. ${ }^{77}$ Furthermore, several leading commentators have suggested that this approach might be feasible for general use in the federal courts. ${ }^{78}$

The Thayer-Wigmore theory is procedural within the meaning of the enabling act and could be adopted by the Supreme Court. ${ }^{70}$ This approach places only the burden of producing sufficient evidence to support the non-existence of the presumed fact upon the party against whom it operates. Regulating management of this burden is essential to the conduct of an efficient trial and the effect of the fact that it may "shift" from one party to the other during

Rules 703 and 704 of the American Law Institute MODEL Codf of Evidence, if adoptcd, will clear up the confusion and give both courts and legislatures a norm for future áction."

${ }^{75}$ See, e.g., Dick v. New York Life Ins. Co., 359 U.S. 437 (1959); Western \& Atl. R.R. v. Henderson, 279 U.S. 639 (1929).

: ${ }^{76}$ See, e.g., Palmer v. Hoffman, 318 U.S. 109 (1943); Cities Serv. Oil Co. v. Dunlap, 308 U.S. 208 (1939); British American Assur. Co. v. Bowen, 134 F.2d 256 (10th Cir. 1943); Rast v. Mutual Life Ins. Co., 112 F.2d 769 (4th Cir. 1940).

${ }^{7 \tau}$ See, e.g., New York Life Ins. Co. v. Gamer, 303 U.S. 161 (1938) (prcsumption against suicide). "Once the employer has carried his burden by offering testimony sufficient to justify a finding of suicide, the presumption falls out of the case." Del Vecchio v. Bowers, 296 U.S. 280, 286 (1935). The principle that the presumption "against suicide shifts only the burden of going forward with the evidence, and does not change the ultimate burden of proof, is so well settled that it scarcely needs a citation of authority." New York Life Ins. Co. v. Taylor, 147 F.2d 297, 301 (D.C. Cir. 1945). See also Jefferson Standard Life Ins. Co. v. Clemmer, 79 F.2d 724 (4th Cir. 1935); McBaine, Burden of Proof: Presumptions, 2 U.C.L.A.L. REv. 13, 22 n.23 (1954).

${ }^{78}$ See Ladd, supra note 66. "Burden of proof rules and presumption rules are of course intimately related. Where they do not operate to set a minimum quantum of proof in particular situations but merely fix or shift the burden of going forward with the evidence it is arguable that the law of the forum state need not be followed." Hill, State Procedural Law in Federal Nondiversity Litigation, 69 HARv. L. REv. 66, 72 n.26 (1955). (Emphasis added.) See also 5 MOORE \ 43.08.

${ }^{70}$ "The doctrine of the burden of proof has two aspects, procedural and sub. stantive. As a matter of procedure it requires the party carrying the burden to come forward with its proofs. As a matter of substantive law the tcrm is frequently uscd to indicate the fact that the burdened party's proof must outweigh the opposing proof in order to establish the claim asserted." United Statcs v. Standard Oil Co., 270 F.2d 50, 59 (2d Cir. 1959). (Emphasis added.) See generally Jefferson Standard Life ins. Co. v. Clemmer, 79 F.2d 724 (4th Cir. 1935); notes 32-34 supra and accompanying text. It must be remembered that the question of whether or not the presumption is procedural or substantive "involves a federal matter upon which state law does not control in applying Erie." 5 MOORE I 43.08, at 1337. 
the course of the trial appears inconsequential. The burden of persuasion, on the other hand, applies only when all the evidence is in, ${ }^{80}$ and although it is very likely to affect substantive rights, it lacks the procedural nature of the burden of producing evidence.

However, the fact that the Thayer-Wigmore doctrine is procedural in nature does not prevent the application of Erie if the presumption will affect the outcome of the litigation. Under a strict "outcome determinative" test the placing of this slight burden could be considered "substantive"; but in fact, the doctrine of Guaranty Trust has not been carried this far. ${ }^{81}$ This slight burden appears no more likely to affect the substantive rights of the parties and the outcome of the litigation than do rules for the admission of hearsay evidence, which are acknowledged to be procedural. ${ }^{82}$ Moreover, the limiting language of Byrd may serve to dispel any lingering doubts concerning possible implications of the Guaranty Trust doctrine. ${ }^{83}$ Employing the Byrd rationale, one could argue that there is a countervailing federal policy favoring uniform operation of the presumption as a procedural device to help determine which party has the burden of producing evidence to avoid a directed verdict. Although not a policy of overwhelming significance, it is one necessary for the smooth operation of trials in the federal district courts and would transcend no important state policy.

Furthermore, the Thayer-Wigmore approach is more likely to be accepted for use in the trial of criminal cases in the federal courts than would the approach found in the Uniform Rules. ${ }^{84}$ While rules for criminal procedure would be adopted under a different act, ${ }^{85}$ uniformity between civil and criminal evidence rules appears

\footnotetext{
${ }^{80}$ Sce note 35 supra.

${ }^{81}$ See notes 26 \&: 27 supra.

s2 Dallas County v. Commercial Union Assur. Co., 286 F.2d 388, 393 (5th Cir. 1961); Preliminary Report on Federal Evidence Rules 40. "It is hard to see how any of the hearsay exceptions could be classified as substantive law under the Erie doctrine...." Ladd, supra note 66, at 709 .

83 "Therefore, were 'outcome' the only consideration, a strong case might appear for saying that the federal court should follow the state practice. But there are affirmative countervailing considerations at work here." Byrd v. Blue Ridge Co-op., 356 U.S. 525, 537 (1958). (Emphasis added.)

at The defendant has "the burden of going forward with the evidence. When he has raised a reasonable doubt he has met this burden. He does not also have the burden of persuasion." Orfield, Burden of Proof and Presumptions in the Federal Criminal Cases, 31 U. KAN. CrTY L. REv. 30, 45 (1963). For a general discussion of presumptions and criminal law, see O'Toole, Artificial Presumptions in the Criminal Law, 11 ST. JoHN's L. Rev. 167 (1937).

${ }^{8 c}$ Such rules would be adopted under 18 U.S.C. $\$ \$ 3771-72$ (1958). The comment
} 
to be a worthy goal ${ }^{86}$ Since the government traditionally must prove its case beyond a reasonable doubt, the Uniform Rules theory of presumptions would at best be ineffectual in the criminal cases. Indeed, placing the burden of persuasion upon the defendant might well violate the defendant's rights. ${ }^{87}$ The comment to Uniform Rule 16 assures that the so called presumption of innocence is not to be affected by Uniform Rule 14, but, in fact this adds nothing, for any presumption in favor of the accused is mere surplusage. ${ }^{88}$ The only useful presumptions against the accused in a criminal case are those which are grounded in "rational connection" and sound policy, and which will be negated by the introduction of rebutting evidence.

to Federal Rule of Criminal Procedure 26, adopted pursuant to the above enabling act, encouraged a decisional reform for criminal evidence law, but the Supreme Court has refused to follow such a course. "We concur in the general opinion of courts, textwriters and the profession that much of this law [criminal evidence] is archaic, paradoxical and full of compromises.... But somehow it has proved a workable even if clumsy system when moderated by the discretionary controls in the hands of a wise and strong trial court. To pull one misshapen stone out of the grotesque structure is more likely simply to upset its present balance between adverse interests than to estab. lish a national edifice." Michelson v. United States, 335 U.S. 469, 486 (1948). (Emphasis added.)

The MODEL PENAL CODE $\$ 1.12(5)$ (1962) proposes an approach to presumptions which is neither a Thayer-Wigmore approach nor that adopted by the Uniform Rules, although it is probably closer to the Thayer-Wigmore approach. See Modec Penst Code $\$ 1.13$, comment at 114-17 (Tent. Draft No. 4, 1955).

${ }^{86}$ See note 68 supra; see generally Orfield, supra note 84.

87 "Strictly speaking, the burden of proof, as those words are understood in criminal law, is never upon the accused to establish his innocence.... It is on the prosecution from the beginning to the end of the trial and applies to every element necessary to constitute the crime." Davis v. United States, 160 U.S. 469, 487 (1895). See also Morissette v. United States, 342 U.S. 246, $275-76$ (1952) (conclusive presumption); Orfield, supra note 84 , at 49 . However, "the burden of going forward with the evidence at some stage of a criminal trial may be placed on the defendant, but only after the State has 'proved enough to make it just for the defendant to be required to repel what has been proved with excuse of explanation'" sufficient to raise a reasonable doubt in the mind of the jury. Speiser v. Randall, 357 U.S. 513, 524 (1958).

It is necessary that the criminal presumption be based upon a rational cornection between the fact proved and the presumed fact. See Yee Hem v. United States, 268 U.S. 178, 183 (1925); Davis v. United States, 274 F.2d 585 (D.C. Cir.), cert. denied, 363 U.S. 806 (1960); Government of Virgin Islands v. Torres, 161 F. Supp. 699 (D. Vir. I. 1958); Orfield, supra note 84 , at 70 , indicates that in some cases the "burden" could be placed upon the defendant; Morgan, Some Further Observations on Presumptions, 16 So. CAt. L. REv. 245, 259 (1943).

${ }^{80}$ Sce, e.g., 9 Wigmore $\$ 2511$; note 56 supra. The same is true for the so called presumption of due care in jurisdictions where the burden of proving contributory negligence is on the defendant. "The statutory presumption of due care is like a handkerchief thrown over something also covered by a blanket." Brown v. Henderson, 285 Mass. 192, 194, 189 N.E. 41, 43 (1934); Falknor, Notes on Presumptions, 15 Wasr. L. REv. 71, 73-74 (1940). 
For example, the presumption against insanity requires that the defendant produce some evidence of insanity if the presumption is to be rebutted. In the federal courts and in most state courts, this burden is met very easily, resulting in the imposition of a burden of proving sanity beyond a reasonable doubt upon the state. ${ }^{80}$ This is, in fact, the basic operation of the Thayer-Wigmore presumption. Thus, the less rigorous Thayer-Wigmore approach would prove useful and practical, particularly in light of the fact that the verdict in a criminal case is never directed in favor of the government.

In conclusion, it is submitted that the Thayer-Wigmore approach to presumptions is the only one feasible for use in the federal district courts. More than likely, the doctrine would escape the rigors of Erie, but if not, it is clearly within the rule-making power of the Supreme Court. The Thayer-Wigmore approach has the added virtue of being simple and easy to administer by the courts. ${ }^{90}$ Except for making sure that the "rational connection" test is met for presumptions that will be used in criminal cases, the drafting of the rules should be fairly easy. The rules adopted by the Model Code should serve as a good starting point. Adoption of the Thayer-Wigmore approach would add a strong element of uniformity in an area of evidence law badly in need of reform. ${ }^{91}$

$$
\text { a.h.g. jr. }
$$

${ }^{80}$ The leading case is Davis v. United States, 160 U.S. 469 (1895), where the Court held that it was proper to require the defendant to rebut the presumption of sanity, and that the defendant "is entitled to an acquittal of the specific crime charged if upon all the evidence there is reasonable doubt whether he was capable in law of committing crime." Id. at 484. The force of the evidence required to rebut the presumption of sanity and make the issue of sanity a jury question which the state must prove beyond a reasonable doubt is not very great. See, e.g., Amador Beltran v. United States, 302 F.2d 48 (Ist Cir. 1962); Hall v. United States, 295 F.2d 26 (4th Gir. 1961); see also Frank v. United States, 42 F.2d 623 (9th Cir. 1930) (burden of proving self defense); Ezzard v. United States, 7 F.2d 808 (8th Cir. 1925) (presumption of guilt from possession). See generally 9 WIGMORE $\$ 2501$.

${ }^{\circ 0}$ Moreover, a substantial number of courts have adopted the Thayer-Wigmore approach. See generally Gausewitz, Presumptions in a One-Rule World, 5 VAND. L. REv. 324, 331 (1952); Morgan, The Law of Evidence, 1941-1945, 59 HARv. L. REv. 481, 495 (1946); Morgan, supra note 87, at 259.

${ }^{02}$ It is further submitted that the drafters of the various codified rules dealing with presumptions have spent too much time debating brain twisting theories and not enough time studying the broad spectrum of evidence reform. A very clumsy situation will be created if the states adopt the Uniform Rules approach and the federal courts can only adopt the Thayer-Wigmore doctrine. Another example of the lack of coordination is $\S 1-201$ (31) of the Uniform Commercial Code which adopts the Thayer-Wigmore doctrine for presumptions arising under that act. Thus, the National Conference of Commissioners is advocating adoption of two sets of uniform laws, each of which has a significantly different rule for the effect to be accorded a presumption. 